\title{
Dispersion of soil gas around micron gold deposits
}

\author{
Stephen E. Kesler ${ }^{\mathrm{a}}$, Michael J. Gerdenich ${ }^{\mathrm{a}}$, Roger C. Steininger ${ }^{\mathrm{b}, \mathrm{l}}$ and \\ Clark Smith ${ }^{\mathrm{b}, 2}$

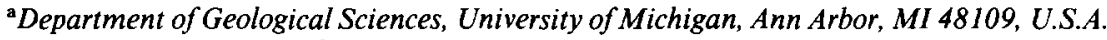

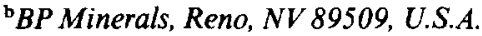

(Received November 23, 1988; revised and accepted September 14, 1989)

\begin{abstract}
Kesler, S.E., Gerdenich, M.J., Steininger, R.C. and Smith, C., 1990. Dispersion of soil gas around micron gold deposits. In: S.E. Kesler (Editor), Soil and Rock Gas Geochemistry. J. Geochem. Explor., 38: 117-132.
\end{abstract}

Experimental weathering of sediment-hosted micron gold (SHMG) ore from the Alligator Ridge deposit indicates that ore and adjacent Pilot Shale wallrock release gas with larger concentrations of COS, $\mathrm{CS}_{2}$ and $\mathrm{CH}_{4}$, and lower $\mathrm{CH}_{4} /\left(\mathrm{CH}_{4}+\mathrm{C}_{2} \mathrm{H}_{4}\right)$ and $\mathrm{CH}_{4} /\left(\mathrm{CH}_{4}+\mathrm{C}_{2} \mathrm{H}_{6}\right)$ ratios than does barren Pilot Shale. The $\mathrm{COS}$ and $\mathrm{CS}_{2}$ are derived from decomposition of disseminated pyrite, which is probably more abundant in mineralized zones, and variations in the $\mathrm{CH}$-gas ratios are thought to reflect increased thermal maturity of organic material in the mineralized zones. Surveys designed to determine whether these gases are present in detectable haloes around SHMG mineralization were carried out over the Yankee prospect, a relatively similar deposit several $\mathbf{k m}$ south of Alligator Ridge. The surveys included analysis of interstitial soil gas, gases desorbed from soils, and gases desorbed from two sets of Carbotrap collectors, one left on the bedrock interface (at depths of about $30-70 \mathrm{~cm}$ below the surface) and another placed in holes drilled about $3 \mathrm{~m}$ into bedrock. All of the gases observed in the experiments were detected, as well as organo-sulfur and higher alkane and alkene gases. The surveys indicated systematic variations in gas dispersal related to faults and/or mineralization, with the most consistent patterns being elevated $\mathrm{COS}$ values and depressed $\mathrm{CH}_{4} /\left(\mathrm{CH}_{4}+\mathrm{C}_{2} \mathrm{H}_{4}\right)$ ratios over mineralization. Similar highs in $\mathrm{COS}$, as well as other gases including $\mathrm{SO}_{2}$ and ethyl mercaptan, were associated with faults, and it was not possible to distinguish these two sources of anomalous gas patterns in all cases. In general, best results were obtained with gases desorbed from bulk soil, and no significant advantage was observed with the use of collectors placed in deep holes. Although all of the survey methods yielded anomalous patterns, none of these patterns are sufficiently strong to merit the use of gas geochemistry as a primary guide in exploration for SHMG deposits.

\section{INTRODUCTION}

Soil-gas surveys have documented the presence of detectable $\mathrm{CO}_{2}, \mathrm{O}_{2}$, hydrocarbon and sulfur gases around sulfide ore bodies and oil and gas fields

\footnotetext{
${ }^{1}$ Present address: 3401 San Mateo Avenue, Reno, NV 89509, U.S.A.

${ }^{2}$ Present address: P.O. Box 19325, Reno, NV 89511, U.S.A.
} 
(Philp and Crisp, 1982; Horvitz, 1985; McCarthy and Reimer, 1986). COS and $\mathrm{CS}_{2}$ have been observed in interstitial soil gas and in gases desorbed from soil above sulfide deposits in Arizona (Hinkle and Dilbert, 1984; Hinkle, 1986) and in other locations throughout the world (van den Boom and Poppelbaum, 1982; Nicholson et al., 1988), indicating that these gases are widespread in all weathering environments. Jones and Drodz (1983) have shown that straight-chain alkane gases are present in soil gases and that the ratio of higher alkane gases to $\mathrm{CH}_{4}$ is highest over oil and gas fields. Although most of the gases recognized in these soil-gas studies contain elements that are present in large amounts in the ore or oil itself, and which are thought to have been derived from that source, other gases have been found in some soil gas studies. For instance, $\mathrm{CO}_{2}$ and $\mathrm{CH}_{4}$, which are anomalously abundant over the Crandon massive $\mathrm{Cu}-\mathrm{Zn}$ sulfide deposit in Wisconsin, are thought to have been derived, respectively, from dissolution of carbonate minerals in overburden by acidic groundwater and from thermal cracking of kerogen in the wallrock (McCarthy et al., 1986).

With the exception of a few studies such as that at Crandon, not much attention has been given to the possibility of using soil-gas surveys to search for deposits where hydrocarbons and sulfur are not major (e.g. $>50 \%$ ) components of the target itself. Sediment-hosted micron gold (SHMG) deposits, which are discussed in this report, are the most obvious example of such an exploration target. These deposits consist of small amounts of gold, commonly at at the ppm level, and larger amounts of arsenic, antimony and other metals (Bagby and Berger, 1985, table 8.4) in carbonaceous limestone or shale with locally intense silicification and kaolinization. Both sulfur, largely in the form of pyrite, and hydrocarbons, in the form of kerogen, are slightly enriched in these deposits, and might form detectable gas haloes. As a test of

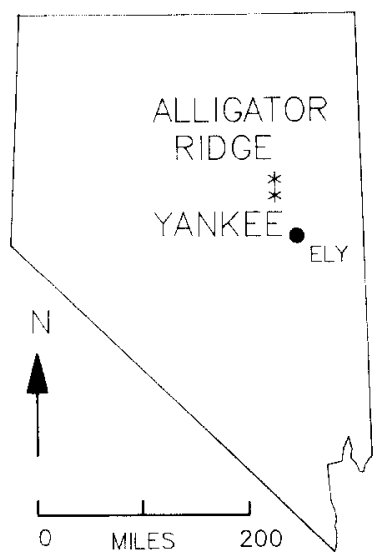

Fig. 1. Location of the Alligator Ridge and Yankee deposits. White Pine County, Nevada. 
this possibility, we carried out field surveys over a number of SHMG deposits and prospects in eastern Nevada using several sample media. We report here the results of surveys carried out at the Yankee prospect, which is located several km south of the Alligator Ridge SHMG deposit (Fig. 1). Yankee is emphasized here because more sample media were tested here than at any other deposit or prospect. Results obtained at Yankee are representative of those from other areas.

\section{FORMATION OF SULFUR AND HYDROCARBON GAS HALOES AROUND SHMG DEPOSITS}

Gases given off by weathering SHMG deposits should differ from those given off by weathering of barren rock for several reasons. In the case of sulfur gases, any enrichment of pyrite, caused by hydrothermal activity in the deposits, should result in the generation of increased amounts of sulfur gases. Although calculations based on the assumption of thermodynamic equilibrium indicate that $\mathrm{H}_{2} \mathrm{~S}$ should be the dominant gas released during the oxidative weathering of sulfide minerals, Taylor et al. (1982) have shown that $\mathrm{COS}$ and $\mathrm{CS}_{2}$ are, in fact, the dominant S-gases and Stedman et al. (1984) have shown that carbon in these gases is derived from organic material. Kesler and Gardner (1986) have shown that $\mathrm{CS}_{2}$ is most common in interstitial soil gas, whereas $\mathrm{COS}$ is more commonly adsorbed onto soil particles. $\mathrm{CS}_{2}$ is likely to be a shortlived gas in the upper part of the soil zone, where it probably oxidizes to several gases, including COS (Sze and Ko, 1979).

The abundance and composition of the hydrocarbon fraction of gases over SHMG deposits should be related to the thermal maturity of the organic matter. Ilchik et al. (1986) have shown that the organic matter at Alligator Ridge is more mature near the ore zone, and Kettler et al. (1990) have demonstrated that the mineralizing fluids oxidized the organic material. Mineralization in the Alligator Ridge SHMG deposits is thought to have occurred at temperatures of about $200^{\circ} \mathrm{C}$ (Ilchik, 1987), which is above the range of temperatures typical of catagenesis (Tissot and Welte, 1978). Although these observations do not indicate exactly what types of hydrocarbon gases should be given off by weathering SHMG deposits, the simplest possibility is that catagenesis associated with mineralization should produce more labile light alkanes such as $\mathrm{CH}_{4}$, in keeping with the production of natural gas at depths and temperatures greater than those commonly needed to form oil (Tissot and Welte, 1978).

As a partial test of these generalizations, laboratory experiments were carried out on mineralized and barren Pilot Shale from the Alligator Ridge mine, as well as on barren shale from the region. Early versions of these experiments simulated weathering by circulating water over crushed sample or by dripping it through a soil/or column with periodic analysis of headspace gas (Taylor 
et al., 1982; Kesler and Gardner, 1986), and demonstrated that weathering ore released large amounts of $\operatorname{COS}$ and $\mathrm{CS}_{2}$, as well as hydrocarbon gases. Further experiments to quantify relative gas abundances were carried out using 1 gram of pulverized rock and $6 \mathrm{ml}$ of water in a $50-\mathrm{ml}$ glass vial with a Minert valve cap. Gases were withdrawn from these vials for analysis after 2 weeks. As can be seen in Figure 2, $\mathrm{CS}_{2}$ and $\mathrm{COS}$ abundances were much higher in ore and wallrock samples than in country rock. $\mathrm{CH}_{4}$ abundances in gases given off by ore samples are also much greater than those in gases from barren country rock and wallrock samples. Although smaller differences were observed in the heavier hydrocarbon gases, the $\mathrm{CH}_{4} /\left(\mathrm{CH}_{4}+\mathrm{C}_{2} \mathrm{H}_{4}\right)$ and $\mathrm{CH}_{4} /$ $\left(\mathrm{CH}_{4}+\mathrm{C}_{2} \mathrm{H}_{6}\right)$ ratios were lowest in ore samples and greatest in barren samples, as would be expected if catagenesis of the mineralized rocks produced abundant $\mathrm{CH}_{4}$ and higher hydrocarbons.

Additional tests were made to determine whether arsine $\left(\mathrm{AsH}_{3}\right)$ could be an important gaseous constituent given off by these deposits during oxidative weathering. Arsine is a strongly reduced gas and would not be stable under oxidative weathering conditions. However, other reduced gases such a $\mathrm{CS}_{2}$ are relatively common around oxidizing sulfide deposits and it is possible that arsine might also persist metastably into more oxidizing environments. These tests involved artificial weathering experiments similar to those discussed above, in which pieces of realgar-rich gold ore were used in place of As-free ore. Sulfur and hydrocarbon gases released in these experiments did not differ from those observed in the other experiments. Gases from these experiments were also analyzed for $\mathrm{AsH}_{3}$ using the gas chromatographic technique of Photovac, Ltd. of Toronto, which employs a photoionization detec-

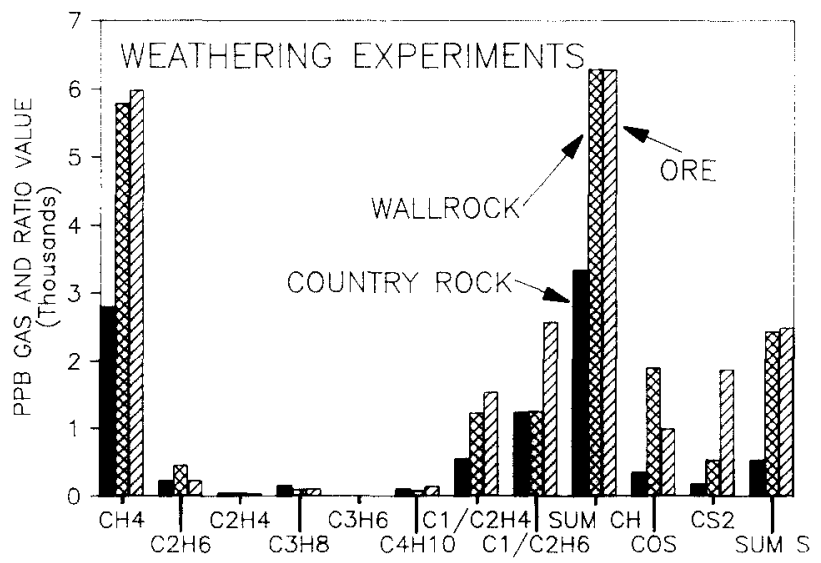

Fig. 2. Bar graph comparing average concentration or ratio value for gases produced by weathering samples of ore, barren wallrock, and unmineralized country rock from the Alligator Ridge SHMG deposit. 
tor with a sensitivity of considerably less than $1 \mathrm{ppb} \mathrm{AsH}_{3}(\mathrm{v} / \mathrm{v})$. Tests with this unit, done under the supervision of Photovac personnel, were completely negative, although it is still possible that arsine is present in gases formed in more reducing weathering environments.

On the basis of these experiments, we designed our field surveys to test for elevated levels of $\mathrm{COS}, \mathrm{CS}_{2}, \mathrm{CH}_{4}$ and depressed levels of the ratios $\mathrm{CH}_{4}$ / $\left(\mathrm{CH}_{4}+\mathrm{C}_{2} \mathrm{H}_{4}\right)$ and $\mathrm{CH}_{4} /\left(\mathrm{CH}_{4}+\mathrm{C}_{2} \mathrm{H}_{6}\right)$ over SHMG mineralization in a variety of sample types.

\section{GEOLOGY OF THE YANKEE SURVEY AREA}

Bedrock in the Yankee area (Fig. 3) consists largely of the Devonian-Mississippian Pilot Shale, which is overlain in the southwestern part of the area by the Mississippian Joana Limestone and float derived from largely eroded Tertiary basalt flows (Klessig, 1984). North- to northwest-trending faults cut the area, and two northeast-trending faults are inferred to cut the central part of the area. Yankee is characterized by widespread low-grade gold mineralization. Delineation of mineralized zones proved to be a significant problem

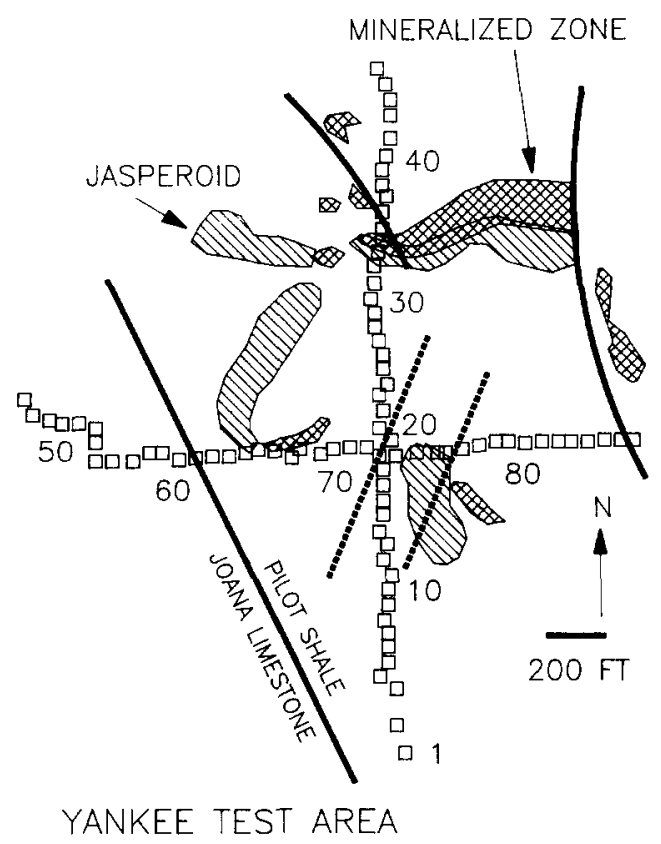

Fig. 3. Schematic geologic map of the Yankee SHMG deposit showing the location of samples along the two traverses discussed in this report and location of faults that cut the traverse. The hachured block marks the location of the northern, shallow ore zone. 
in designing our field sampling tests, particularly because the sampling programs coincided with the latter phase of drilling activity. The zones of mineralization shown on Figure 3 were outlined by contouring the parameter:

\section{(Grade) X (Thickness/Depth to Ore)}

and outlining a constant value. This approach was used, rather than simply outlining gold mineralization of similar intensity regardless of its depth, because near-surface mineralization should yield more gases than deeper mineralization of the same grade. Regardless of these uncertainties, it was clear that the largest, shallowest zone of gold is in and near an east-trending jasperoid in the northern part of the area (Fig. 3). The smaller zones of mineralization shown in the central part of the area are the highest grade and/or shallowest parts of a larger zone of more deeply buried, low grade mineralization. Fault zones in the area, which were delineated by a combination of field and photo indications, appear to terminate the northern ore zone on the west, and two probable faults cut the central ore zone.

The Yankee prospect has been weathered to depths of several tens of meters, and most pyrite and organic material have been removed. Although extensively weathered rocks such as this are probably not as strong a source of gases as are rocks that are only partly weathered, they are typical of wallrocks that host many SHMG prospects and, as such, must be evaluated. Our soilgas studies in other, less weathered SHMG prospects in Nevada did not detect significant differences in gas abundances or species, suggesting that some of the gases released during oxidation are adsorbed and retained by wallrocks even after extensive weathering.

\section{SAMPLE LOCATIONS, SAMPLE TYPES AND COLLECTION PROCEDURES}

Samples discussed in this report were collected along two mutually perpendicular traverses that crossed the northern, shallow and central, deeper mineralized zones. A large number of survey types were carried out along the north-south traverse, which crosses the shallow ore zone, and most of this report is based on results from that traverse. Overburden in the Yankee area consists of thin $(0.3-1 \mathrm{~m})$ immature soils developed on Pilot shale bedrock. Vegetation consists essentially of small, widely spaced, juniper and pinyon trees. Surface disturbance of the test area was limited to a few drill roads and numerous drill pads. Surveys described here were carried out in two stages. In the summer of 1984, surveys were based on interstitial soil gas, and gases desorbed from both soils and collectors, which were placed in shallow, 30- to $70-\mathrm{cm}$ holes that bottomed in bedrock. In the summer of 1985 , a second set of collectors was placed in holes drilled to depths of about $3 \mathrm{~m}$ into bedrock in an attempt to obtain stronger gas signals with less surface contamination.

Soil samples were obtained by digging holes with a shovel to the bedrock 
interface where about $50 \mathrm{~g}$ of soil were removed and stored in 4 mil polyethylene bags and glass vials. Soil gas was obtained by driving a metal probe about $1 \mathrm{~m}$ into the ground, and allowing a gas sample to flow into an evacuated $280-\mathrm{cm}^{3}$ stainless steel container. Pressure checks following gas collection showed that most containers were only about $80 \%$ full, indicating that free leakage of atmosphere into the samples did not occur. Assuming an average porosity of $30 \%$, the $225 \mathrm{~cm}^{3}$ of gas recovered at each station could have come from a cubic volume of soil measuring about $9 \mathrm{~cm}$ on a side.

Collectors used for both the shallow and deep surveys were constructed of glass vials, which were covered by a 325 mesh polyester screen attached to the mouth of the vial with galvanized steel wire. The absorbent used in the vials was $1 \mathrm{~cm}^{3}$ of Carbotrap, a gas absorbent manufactured by Supelco, Inc., which was heated previously to $200^{\circ} \mathrm{C}$ to clean it of adsorbed gases. This material was chosen after absorbent tests carried out on a variety of chromatographic column compounds indicated that it absorbed the largest amounts and variety of sulfur and hydrocarbon gases important to this study. Vials containing the Carbotrap were capped with open-top, screw caps lined with Teflon septa for transportation to and from the field site. For the shallow tests, the 6-ml vials were suspended in an inverted position in small plastic sleeves at the bottom of the holes used for soil samples, where they were left from July to September, 1984. The deep survey collectors were planted in holes that were drilled to an average depth of $3 \mathrm{~m}$ using an Air Track percussion drill. The upper $60 \mathrm{~cm}$ of these holes were drilled with water, but deeper parts of the holes were drilled dry. The holes were cased with $3.13 \mathrm{~cm}$ (1.25 in) ID PVC pipe and the area around the casing was sealed with soil and cuttings to impede influx of surface gases. Collectors consisting of $20-\mathrm{ml}$ glass vials with $1 \mathrm{~cm}^{3}$ of Carbotrap were inverted in the casing about $5 \mathrm{~cm}$ from the bottom of the holes suspended by steel wire. The casing, which was left open to permit removal of the vials, capped with aluminum metal and sealed with Scotch AllWeather tape. The collectors were left in these holes from late July to midOctober, 1985. Unopened collectors were left at the field site and in the lab for later comparison.

\section{ANALYTICAL PROCEDURES}

All analyses reported here were obtained using a Tracor 560 gas chromatograph with a flame ionization detector (FID) for hydrocarbon gases and a Hall electrolytic conductivity detector (HECD) for sulfur gases. This system permitted simultaneous analysis for $\mathrm{H}_{2} \mathrm{~S}, \mathrm{CS}_{2}, \mathrm{COS}, \mathrm{SO}_{2}$, methyl mercaptan (MSH or $\mathrm{CH}_{3} \mathrm{SH}$ ), ethyl mercaptan (ESH or $\mathrm{C}_{2} \mathrm{H}_{5} \mathrm{SH}$ ), dimethyl sulfide (DMS or $\mathrm{C}_{2} \mathrm{H}_{6} \mathrm{~S}$ ), dimethyl disulfide (DMDS or $\mathrm{C}_{2} \mathrm{H}_{6} \mathrm{~S}_{2}$ ), $\mathrm{CH}_{4}, \mathrm{C}_{2} \mathrm{H}_{6}, \mathrm{C}_{3} \mathrm{H}_{3}$, $\mathrm{C}_{4} \mathrm{H}_{10}, \mathrm{C}_{2} \mathrm{H}_{4}$, and $\mathrm{C}_{3} \mathrm{H}_{6}$. Detection limits for all gases were in the lower ppb range for a 3-ml gas sample. Gases were removed from their respective con- 
tainers with a Pressure-Lok syringe, compressed to slightly greater than atmospheric pressure in the syringe, and injected onto two, in-series, 3-ml sample loops attached to a 12-port valve. This valve was used to switch the contents of one loop onto a Chromosil 330 column (Supelco) leading to the HECD and the contents of the other loop onto a VD-7 column (Supelco) leading to the FID. The columns were operated at a constant temperature of $55^{\circ} \mathrm{C}$ with a He gas flow of $30 \mathrm{~cm}^{3} \mathrm{~min}^{-1}$.

Gas was removed from the stainless steel containers without heating or other preparation and injected directly into the sample loop of the gas chromatograph. Soils were degassed in two ways. The low temperature fraction of soil gas was desorbed by placing a 2-g aliquot in a glass vial capped by a plastic lid with a Teflon-lined septum, heating the vials to $70^{\circ} \mathrm{C}$ overnight in an oven, and allowing them to cool before analysis (van den Boom and Poppelbaum, 1982). This method does not destroy the water layer that can trap gases around particles and thus only liberates relatively lightly adsorbed gases. Heating of the same samples to temperatures high enough to evaporate this water layer to release more strongly adsorbed gases failed when expansion of water vapor caused the Teflon septa to burst; water vapor also impeded column efficiency. Accordingly, glass vials containing soils from which the low temperature gas fraction had been desorbed at $70^{\circ} \mathrm{C}$, were opened, heated for two hours at $70^{\circ} \mathrm{C}$ to remove excess moisture, and then closed and heated to $125^{\circ} \mathrm{C}$ overnight before analysis. In all cases, gas abundances desorbed at $125^{\circ} \mathrm{C}$ were $10-20$ times greater than those desorbed at $70^{\circ} \mathrm{C}$. Collector vials, which were also capped with Teflon-lined septa, were heated to $200^{\circ} \mathrm{C}$ for 2 minutes (shallow survey) and 5 minutes before removing gas for analysis.

Analytical response from the gas-chromatograph detectors were recorded on Spectra-Physics $\mathbf{4 2 0}$ peak integrators and reported as peak areas. Results were standardized by comparison to peak areas for standard gas compositions similar to the unknowns. Individual peaks on chromatograms were identified by comparison to the retention time for known gases injected under the same analytical conditions. Sulfur gas standards were obtained using a permeation tube system that released about $100 \mathrm{ppm} \mathrm{COS}$ and $\mathrm{CS}_{2}$, and for hydrocarbon gases with commercial standards containing about $20 \mathrm{ppm}$ of each gas. All sample compositions are expressed as ppb gas in the headspace of the container, which was constant because all sample volumes were constant. Replicate analyses of the same sample over extended periods indicated precision of about $\pm 30 \%$ ( 2 s.d.) for sulfur gases and $\pm 10 \%$ for hydrocarbon gases. Analyses of duplicate samples from the same location indicated differences of up to $\pm 50 \%$ for duplicate pairs, with the greatest differences observed for samples with the lowest gas contents. Although these results make it clear that duplicate samples from individual soil gas sample sites exhibit greater variation than is observed in more commonly applied geochemical survey methods, the variation observed between different sample stations is 
much greater than this analytical and sampling variation, and geologically important differences in gas evolution patterns can be recognized throughout the survey area.

\section{RESULTS OF THE GAS SURVEYS}

The Yankee survey indicates that different sample types detected similar gas patterns and that anomalous values coincide with mineralization and faults. Most of the anomalous patterns are not strong, however. The results of each of the sample types are summarized below, with an emphasis on the north-south traverse, where all four types of surveys were run (in contrast to the east-west traverse on which only the soil-gas and deep collector surveys were carried out ).

The interstitial soil-gas survey provided evidence for a strong low in the $\mathrm{CH}_{4} /\left(\mathrm{CH}_{4}+\mathrm{C}_{2} \mathrm{H}_{4}\right)$ ratio over the shallow ore zone in the northern part of the area and less well defined lows over the deeper fault and mineralized zones to the south (Fig. 4A). The $\mathrm{CH}_{4} /\left(\mathrm{CH}_{4}+\mathrm{C}_{2} \mathrm{H}_{6}\right)$ ratio exhibited a generally similar pattern, but the stronger lows were over the deep ore zone rather than the shallow one (Fig. 4A). $\mathrm{CH}_{4}$ response over these zones was not strongly anomalous, although the higher values clustered over the shallow ore zone (Fig. 4B). Results for $\mathrm{COS}$ and $\mathrm{CS}_{2}$ soil gas were obtained during two traverses, one in July and the other in August, 1984. Although gas abundances were higher in the August traverse (Fig. 4B), the July traverse contained anomalies with stronger contrast. The southern of the two July traverse anomalies, both of which consisted largely of $\mathrm{CS}_{2}$, coincides with a possible fault, but the northern one is unexplained.

Gases desorbed from the shallow, Carbotrap collectors exhibited similar minima in the $\mathrm{CH}_{4} /\left(\mathrm{CH}_{4}+\mathrm{C}_{2} \mathrm{H}_{4}\right)$ and $\mathrm{CH}_{4} /\left(\mathrm{CH}_{4}+\mathrm{C}_{2} \mathrm{H}_{6}\right)$ ratios over the northern, shallow ore zone, and large minima south of the deeper ore zone (Fig. $4 \mathrm{C}$ ). $\mathrm{CH}_{4}$ abundances are highest in the northern part of the traverse, generally over the ore zones. $\mathrm{CS}_{2}, \mathrm{COS}$ and $\mathrm{COS}+\mathrm{CS}_{2}$ exhibit less variation, although ore zones are associated with elevated values (Fig. 4D).

Gases desorbed from the soil samples differed greatly, with the lower temperature desorbtion yielding results similar to those observed for the vacutainers and shallow collectors. The bulk soils, from which gases were desorbed at $70^{\circ} \mathrm{C}$, exhibit $\mathrm{CH}_{4}$ maxima and $\mathrm{C}_{2} \mathrm{H}_{4}$ and $\mathrm{C}_{2} \mathrm{H}_{6}$ ratio minima over or near the mineralized zones (Fig. 5A,B). Note that the largest $\mathrm{CH}_{4}$ levels are associated with the shallowest mineralization. Sulfur gas abundances do not exhibit much variation, although they show poorly defined maxima over mineralization (Fig. 5B). Soils from the east-west traverse (which were collected from only part of the stations) exhibited a strong $\mathrm{C}_{2} \mathrm{H}_{4}$ ratio anomaly over the deep ore zone and less well defined $\mathrm{C}_{2} \mathrm{H}_{6}$ ratio and $\mathrm{COS}$ anomalies (Fig. $5 C, D)$. Gases desorbed from sieved soil also show $\mathrm{C}_{2} \mathrm{H}_{4}$ ratio minima over 

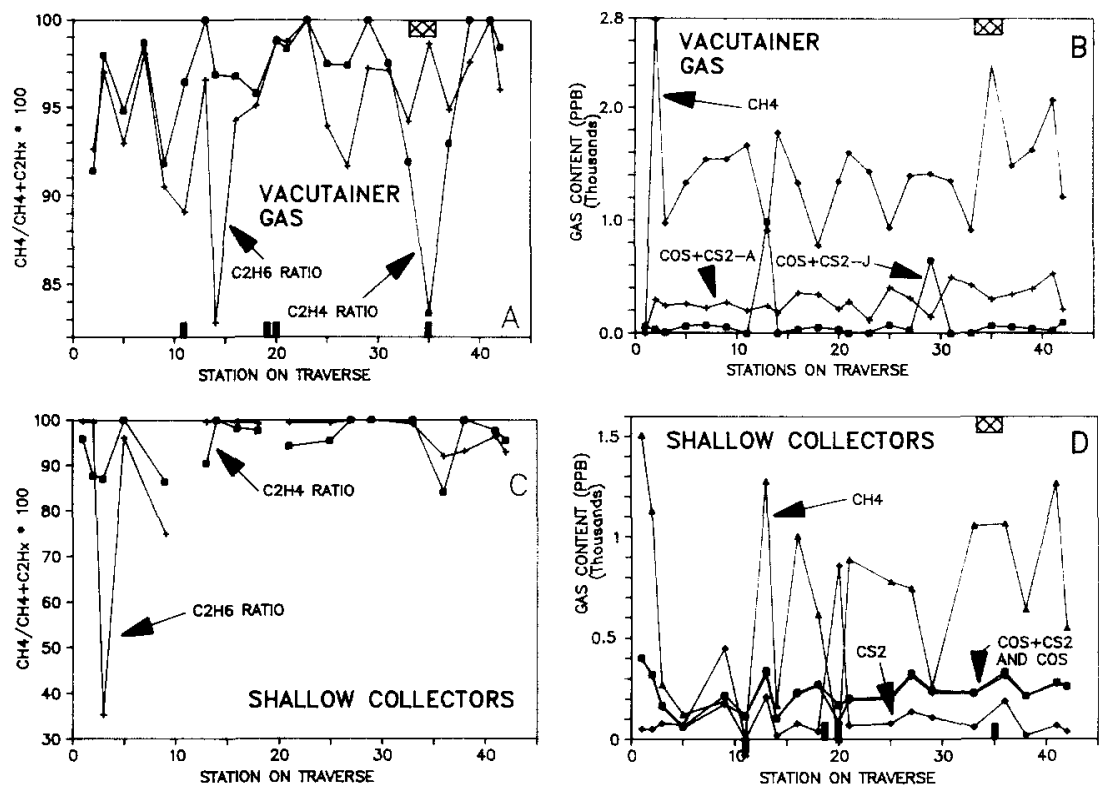

Fig. 4. Results obtained for vacutainer $(A, B)$ and shallow Carbotrap collectors along the northsouth traverse. Fault zones are shown by dark lines at base of traverse and mineralized zones are shown by hatchured zones.

A) Values of the ratios $\mathrm{CH}_{4} /\left(\mathrm{CH}_{4}+\mathrm{C}_{2} \mathrm{H}_{4}\right)$ and $\mathrm{CH}_{4} /\left(\mathrm{CH}_{4}-\mathrm{C}_{2} \mathrm{H}_{6}\right)$ for survey carried out in August, 1984.

B) Concentrations of $\mathrm{CH}_{4}$ (for a survey in August, 1984) and COS $+\mathrm{CS}_{2}$ (for surveys in July and August, 1984). Fault locations are not shown because of overlap with gas abundance data. $\mathrm{C}$ and D. Results obtained for gases desorbed from Carbotrap collectors placed in shallow holes along the north-south traverse at the Yankee deposit. Additional symbols are explained in caption for Figure 4A.

C. Values of $\mathrm{CH}_{4} /\left(\mathrm{CH}_{4}+\mathrm{C}_{2} \mathrm{H}_{4}\right)$ and $\mathrm{CH}_{4} /\left(\mathrm{CH}_{4}+\mathrm{C}_{2} \mathrm{H}_{6}\right)$ ratios.

D. $\mathrm{CH}_{4}, \mathrm{COS}, \mathrm{CS}_{2}$ (multiplied by 10 ) and $\mathrm{COS}+\mathrm{CS}_{2}$ concentrations.

the mineralized zones, but no $\mathrm{C}_{2} \mathrm{H}_{6}$ ratio minima (Fig. 5E). $\mathrm{CH}_{4}$ and sulfur gas patterns are more erratic, with minima over the shallow ore zone and weak to strong maxima over the southern, deeper ore zone (Fig. $5 \mathrm{~F}$ ).

The deep collectors, which were placed in 3-m-deep holes, yielded a different gas suite than did the shallow collectors and, in most cases, less total gas. Whereas $\mathrm{CH}_{4}, \mathrm{C}_{2} \mathrm{H}_{4}, \mathrm{C}_{2} \mathrm{H}_{6}, \mathrm{C}_{3} \mathrm{H}_{6}, \mathrm{C}_{3} \mathrm{H}_{8}$ and heavier hydrocarbons were detected from the shallow collectors, only $\mathrm{CH}_{4}, \mathrm{C}_{2} \mathrm{H}_{4}, \mathrm{C}_{2} \mathrm{H}_{6}$, and two heavier, unidentified hydrocarbon gases were detected from the deep collectors. Furthermore, $\mathrm{CH}_{4}$ abundances in gases desorbed from the deep collectors did not vary significantly and ranged near $4 \mathrm{ppm}$, which is the same amount of $\mathrm{CH}_{4}$ desorbed from a blank collector that was never opened in the field. In spite of these disappointingly low gas yields, the gases that were adsorbed by the col- 

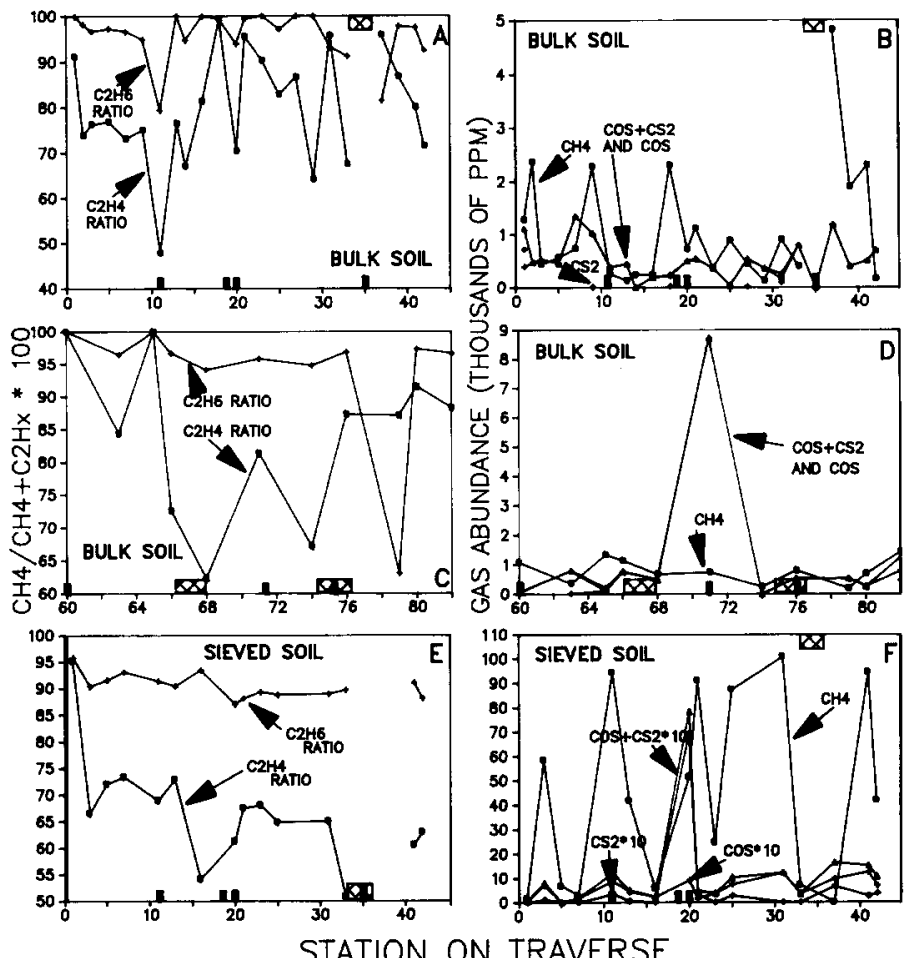

Fig. 5. Results obtained for gases desorbed from bulk soil at $70^{\circ} \mathrm{C}$ and from sieved soil at $125^{\circ} \mathrm{C}$ for soil samples collected along the north-south and east-west traverses at Yankee. Additional symbols explained in caption for Figure 4A.

A. Values of the $\mathrm{CH}_{4} /\left(\mathrm{CH}_{4}+\mathrm{C}_{2} \mathrm{H}_{4}\right)$ and $\mathrm{CH}_{4} /\left(\mathrm{CH}_{4}+\mathrm{C}_{2} \mathrm{H}_{6}\right)$ ratios for bulk soils $\left(70^{\circ} \mathrm{C}\right)$ along the north-south traverse.

B. $\mathrm{CH}_{4}, \mathrm{COS}, \mathrm{CS}_{2}$ and $\mathrm{COS}+\mathrm{CS}_{2}$ abundances for bulk soils $\left(70^{\circ} \mathrm{C}\right)$ along the north-south traverse.

C. Values of the $\mathrm{CH}_{4} /\left(\mathrm{CH}_{4}+\mathrm{C}_{2} \mathrm{H}_{4}\right)$ and $\mathrm{CH}_{4} /\left(\mathrm{CH}_{4}+\mathrm{C}_{2} \mathrm{H}_{6}\right)$ ratios for bulk soils $\left(70^{\circ} \mathrm{C}\right)$ along the east-west traverse.

D. $\mathrm{CH}_{4}, \mathrm{COS}, \mathrm{CS}_{2}$ and $\mathrm{COS}+\mathrm{CS}_{2}$ abundances for bulk soils $\left(70^{\circ} \mathrm{C}\right)$ along the east-west traverse. E. Values of the $\mathrm{CH}_{4} /\left(\mathrm{CH}_{4}+\mathrm{C}_{2} \mathrm{H}_{4}\right)$ and $\mathrm{CH}_{4} /\left(\mathrm{CH}_{4}+\mathrm{C}_{2} \mathrm{H}_{6}\right)$ ratios for sieved soils $\left(125^{\circ} \mathrm{C}\right)$ along the north-south traverse.

F. $\mathrm{CH}_{4}, \mathrm{COS}, \mathrm{CS}_{2}$, and $\mathrm{COS}+\mathrm{CS}_{2}$ abundances for sieved soils $\left(125^{\circ} \mathrm{C}\right)$ along the north-south traverse.

lectors appear to reflect a deeper environment consistent with their location. The constancy in the $\mathrm{CH}_{4}$ probably reflects fewer microbial sources of this gas below the soil zone (Schoell, 1988), and consequent smaller variability in abundance of this gas within the bedrock. More importantly, the fact that $\mathrm{C}_{2} \mathrm{H}_{6}$ is much more abundant than $\mathrm{C}_{2} \mathrm{H}_{4}$ in the deep collectors than it is in the shallow collectors (compare Figs. $4 \mathrm{C}$ and $6 \mathrm{~B}$ ) is consistent with the ob- 
servation that most $\mathrm{C}_{2} \mathrm{H}_{4}$ is a product of microbial activity in the soil horizon (Van Cleemput and El-Sebaay, 1985). Sulfur gases desorbed from the deep collectors (Fig. 6C) differed from those seen in the shallow collector survey in having a significant content of $\mathrm{SO}_{2}$, apparently derived from weathering of sulfide minerals in the surrounding rocks.

As can be seen in Figure 6B, the $\mathrm{C}_{2} \mathrm{H}_{6}$ ratio along the north-south traverse exhibits a distinct minimum over the northerly, shallow ore zone and a few low values over the southerly, deep ore zone. Sulfur gas patterns from the
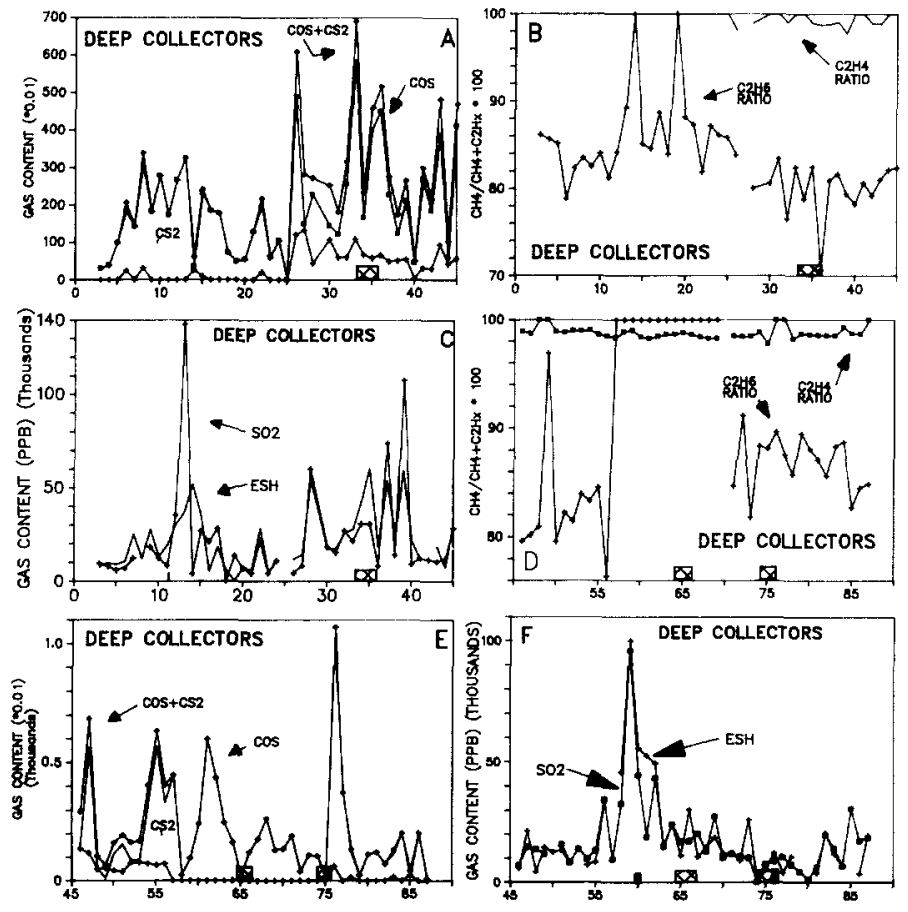

STATION ON TRAVERSE

Fig. 6. Results obtained for Carbotrap collectors placed in 3-m holes along the north-south and east-west traverses at Yankee. Symbols are explained in caption for Figure 4A.

A. $\mathrm{COS}, \mathrm{CS}_{2}$, and $\mathrm{COS}+\mathrm{CS}_{2}$ abundances along the north-south traverse. $\mathrm{CH}_{4}$ abundances do not vary enough to merit plotting them.

B. $\mathrm{CH}_{4} /\left(\mathrm{CH}_{4}+\mathrm{C}_{2} \mathrm{H}_{4}\right)$ and $\mathrm{CH}_{4} /\left(\mathrm{CH}_{4}+\mathrm{C}_{2} \mathrm{H}_{6}\right)$ ratios for gases desorbed from deep collectors along the north-south traverse.

C. $\mathrm{SO}_{2}$ and ESH (ethyl mercaptan) abundances for gases desorbed from deep collectors along the north-south traverse.

D. $\mathrm{COS}, \mathrm{CS}_{2}$ and $\mathrm{COS}+\mathrm{CS}_{2}$ abundances along the north-south traverse. $\mathrm{CH}_{4}$ abundances do not vary enough to merit plotting.

E. $\mathrm{CH}_{4} /\left(\mathrm{CH}_{4}+\mathrm{C}_{2} \mathrm{H}_{4}\right)$ and $\mathrm{CH}_{4} /\left(\mathrm{CH}_{4}+\mathrm{C}_{2} \mathrm{H}_{6}\right)$ ratios for gases desorbed from deep collectors along the east-west traverse.

F. $\mathrm{SO}_{2}$ and ESH (ethyl mercaptan) abundances for gases desorbed from deep collectors along the east-west traverse. 
deep collectors are generally ambiguous with maxima over the northern part of the survey area and lower values to the south (Fig. 6A). Individual maxima are not clearly associated with specific ore or fault zones. $\mathrm{SO}_{2}$ and ethyl mercaptan, which were also desorbed from the deep collectors, showed strongly correlated response, with maxima over the northerly, shallow ore zone and over the southern end of the deep ore zone (Fig. $6 \mathrm{C}$ ). Deep collectors along the east-west traverse did not show $\mathrm{C}_{2} \mathrm{H}_{4}$ or $\mathrm{C}_{2} \mathrm{H}_{6}$ ratio anomalies, but showed strong COS anomalies that appeared to be controlled largely by faults, particularly the fault at the Joana-Pilot contact (Fig. 6D,E). $\mathrm{SO}_{2}$ and ethyl mercaptan response along this traverse is limited to a strong maximum over the fault at the Joana-Pilot contact (Fig. 6F).

\section{DISCUSSION AND CONCLUSIONS}

The results of the survey along the north-south traverse are summarized in Figure 7, which shows the number of anomalous values obtained at each of the stations. Values were categorized as anomalous if they exceeded 1.5 standard deviations from the mean for that population. As can be seen here, the traverse contains three zones with contiguous anomalous values. Two of the three zones are over known ore zones. The third is at the south end of the traverse in the area of ore that was delineated by drilling after this survey. Several of the stations over the shallow, northern ore zone were distinctive in

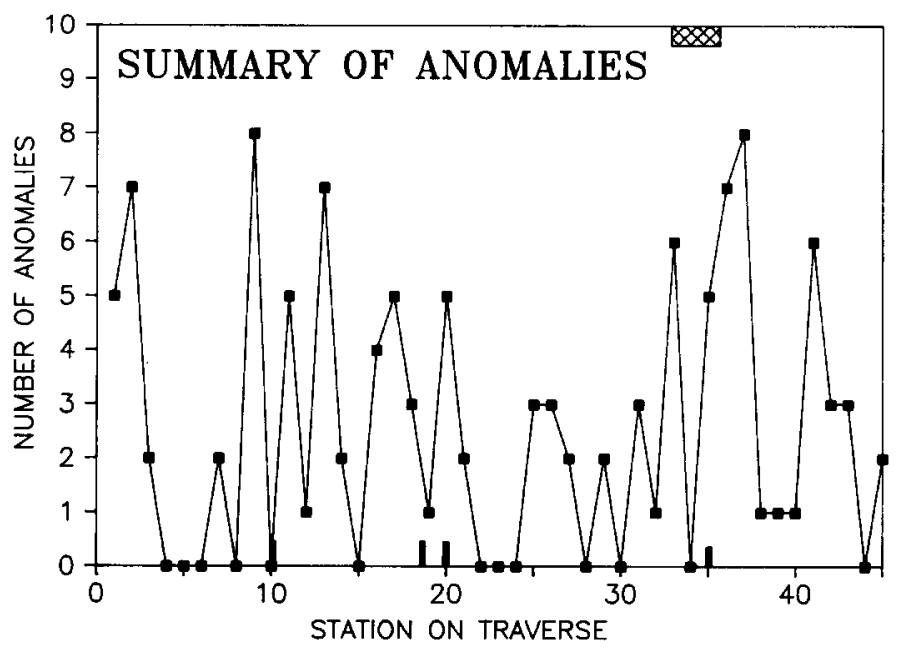

Fig. 7. Summary of anomalies obtained for stations along the north-south traverse. Summary is shown as the percentage of anomalous values for each station because each station did not yield samples for each survey. Samples were defined as anomalous if they deviated from the mzan by 1.5 standard deviations. 
that the same anomaly was obtained from several different sample types. For instance, station 33 exhibited anomalies for the $\mathrm{C}_{2} \mathrm{H}_{4}$ ratio in the vacutainer, bulk soil and sieved soil traverses and $\mathrm{COS}$ anomalies in the vacutainer and deep collector traverses. Stations 35, 36 and 37 had COS anomalies in the vacutainer, shallow collector, bulk soil and deep collector surveys and $\mathrm{C}_{2} \mathrm{H}_{4}$ ratio anomalies in the vacutainer, shallow collector and deep collector surveys. Station 41 yielded $\mathrm{CH}_{4}$ anomalies for the vacutainer, shallow collector, bulk and sieved soil surveys, as well as COS anomalies for the vacutainer and sieved soil traverse.

These results indicate that soil-gas compositions vary systematically with respect to geological features and that these variations can be detected by several different gas sample media. It is clear from our results that faults are zones of enhanced gas movement. For instance, the fault that cuts the northern, shallow ore zone and is intersected at station 36 by the north-south traverse, exhibits 7 anomalies, and the fault at station 59 on the east-west traverse, which was crossed by only the deep gas traverse, exhibits strong anomalies for the sulfur gases. However, the zone of deep mineralization at the southern end of the north-south traverse is characterized by several anomalous stations that do not appear to be associated with faults, suggesting that at least some of the gas patterns observed here did not arrive at the surface along faults. Although it might be suggested that $\mathrm{CH}_{4}$, which can be derived from deep basin sources as well as near surface microbial activity (Schoell, 1988), would be more important than sulfur gases along faults, no support for this possibility is provided by our data.

Although gas anomalies were detected over SHMG ore, our data show that anomalies are also common in areas apparently lacking ore. Furthermore, gas concentrations tend to be relatively erratic compared to standard geochemical indicators. For these reasons, gas geochemistry does not have much appeal in exploration for near-surface ore where the host rock unit is widely exposed. These problems are not resolved by using a sampling method that reaches to depths below the soil horizon. In fact, it appears that satisfactory results can be obtained using gases desorbed from soil or gases extracted from interstitial space in soil, and that the use of collectors at any level does not result in a significant improvement in performance. Complications might also be encountered in attempts to use the same hydrocarbon gases observed in this survey in exploration for SHMG deposits elsewhere in Nevada because the thermal maturity of organic material in the Alligator Ridge area is relatively low in relation to most other parts of the Great Basin (Poole et al., 1983).

In spite of this negative assessment, there are situations in which gas geochemistry might be of use in exploration. The most obvious of these is one in which thick alluvial or other transported overburden obscures bedrock and limited information can be obtained from more conventional geological and geophysical methods. In these cases, soil-gas geochemistry might be used to 
trace faults and possibly to generate anomalies that could be used in conjunction with other survey methods such as vegetation geochemistry to identify anomalous areas for shallow drilling.

\section{ACKNOWLEDGEMENTS}

This study was supported by Amselco Exploration, a division of BP Minerals, and the the Scott Turner Fund of the University of Michigan. Numerous Amselco personnel, including Doug Bowden, Alan Glaser, Rich Hasler and Pam Klessig, were of great help to us during sampling and data interpretation. Reviews by Arthur Rose and Margaret Hinkle brought several ambiguous points to our attention and improved the manuscript. We are grateful to all of these groups and individuals for their help and to BP Minerals for permission to publish this summary of results.

\section{REFERENCES}

Bagby, W.C. and Berger, B.R., 1985. Geologic characteristics of sediment-hosted, disseminated, precious-metal deposits in the western United States. Rev. Econ. Geol., 2: 169-202.

Hinkle, M.E., 1986. Using volatile constitutents of soil and soil gases to determine the presence of copper-zinc ore bodies at Johnson Camp, Arizona. J. Geophys. Res., 91: 12359-12365.

Hinkle, M.E. and Dilbert, G.A., 1984. Gases and trace elements in soils at the North Silver Bell deposit, Pima County, Arizona. J. Geochem. Explor., 20: 323-336.

Horvitz, L., 1985. Geochemical exploration for petroleum. Science, 229: 821-827.

Ilchik, R.P., 1987. Geology and preliminary stable isotope chemistry of the Alligator Ridge disseminated gold deposits. Geol. Soc. Am., Abstracts with Programs, 19(7): 712.

Ilchik, R.P., Brimhall, G.H. and Schull, H.W., 1986. Hydrothermal maturation of indigenous organic matter at the Alligator Ridge gold deposits, Nevada. Econ. Geol., 81: 113-130.

Jones, V.T. and Drozd, R.J., 1983. Prediction of oil or gas potential by near-surface geochemistry. Bull. Am. Assoc. Pet. Geol., 67: 932-952.

Kesler, S.E. and Gardner, M.J., 1986. Factors affecting sulfur gas anomalies in overburden. J. Geophys. Res., 91 (B12): 12339-12342.

Kettler, R.M., Kesler, S.E. and Meyers, P.A., in press. Oxidation of aliphatic hydrocarbons during gold deposition: Alligator Ridge, Nevada. Econ. Geol.

Klessig, P.J., 1984. History and geology of the Alligator Ridge gold mine, White Pine County, Nevada. In: J.L. Johnson (Editor), Exploration for Ore Deposits of the North American Cordillera. Association of Exploration Geochemists 1984 Regional Symposium, pp. FT2-27 to FT2-35.

McCarthy, J.H. and Reimer, G.M., 1985. Advances in soil gas exploration for natural resources: some current examples and practices. J. Geophys. Res., 91 (B12): 12327-12338.

McCarthy, J.H., Jr., Lambe, R.N. and Dietrich, J.A., 1986. A case study of soil gases as an exploration guide in glaciated terrain - Crandon massive sulfide deposits, Wisconsin. Econ. Geol., 81: 1408-420.

Nicholson, R.A., Peachey, D. and Ball, T.K., 1988. Tests on use of sulphur gases in soils to detect hidden mineralization. Trans. Inst. Min. Metall., Sect. B., 97: B57-B63.

Philp, R.P. and Crisp, P.T., 1982. Surface geochemical methods used for oil and gas prospecting - a review. J. Geochem. Explor., 17: 1-34. 
Poole, F.G., Claypool, G.E. and Fouch, T.D., 1983. Major episodes of petroleum generation in part of the northern Great Basin. Geotherm. Resour. Counc. Spec. Rep., 13: 207-213.

Schoell, M., 1988. Multiple origins of methane in the earth: Chem. Geol., 71: 1-10.

Stedman, D.H., Creech, M.Z., Cloke, P.L., Kesler, S.E. and Gardner, M.J., 1984. Formation of $\mathrm{CS}_{2}$ and $\mathrm{COS}$ from decomposition of metal sulfides. Geophys. Res. Lett., 11: 858-860.

Sze, N.D. and Ko, M.K.W., 1979. Is $\mathrm{CS}_{2}$ a precursor for atmospheric COS? Nature, 278: 731 732.

Taylor, C.H., Kesler, S.E. and Cloke, P.L., 1982. Sulfur gases produced by the decomposition of sulfide minerals: application to geochemical exploration. J. Geochem. Explor., 17: 165186.

Tissot, B.P. and Welte, D.H., 1978. Petroleum Formation and Occurrence. Springer-Verlag, New York, NY, 538 pp.

Van Cleemput, O. and El-Sebaay, A.S., 1985. Gaseous hydrocarbons in soil. Adv. Agronomy, 35: $159-181$.

van den Boom, G. and Poppelbaum, M., 1982. Volatile compounds in the soil as indicators in geochemical exploration for concealed ore deposits. Geol. Jahrb., 58: 3-30. 